\title{
Scientific Thinking Skills: Why Junior High School Science Teachers Cannot Use Discovery and Inquiry Models In Classroom
}

\author{
Erman $^{1}$ \\ Science Education Department \\ Universitas Negeri Surabaya \\ Surabaya, Indonesia \\ 1erman@unesa.ac.id

\section{Wasis $^{2}$} \\ Physics Education \\ Universitas Negeri Surabaya \\ Surabaya, Indonesia \\ ${ }^{2}$ wasis@unesa.ac.id
}

\author{
Endang Susantini ${ }^{3}$ \\ Biology Department \\ Universitas Negeri Surabaya \\ Surabaya, Indonesia \\ 3endangsusantini@unesa.ac.id \\ Utiya Azizah ${ }^{4}$ \\ Chemistry Department \\ Universitas Negeri Surabaya \\ Surabaya, Indonesia \\ 4utiyaazizah@unesa.ac.id
}

\begin{abstract}
This study aims to describe the difficulty of the teacher in distinguishing the implementation of discovery and inquiry learning models in science learning and the factors that led to the scientific thinking skills of junior high school science teachers. The case study design used in this study involved 16 science junior high school teachers in East Lombok who have difficulties in distinguishing discovery and inquiry learning models as research samples. The results showed the teachers had scientific thinking difficulties, ranging from observing to identify problems/questions, formulating hypotheses, thinking deductively, and inductive thinking, distinguishing data characteristics and processing, and drawing conclusions. Therefore, teachers should learn scientific thinking skills in order to facilitate learning and trigger students' scientific thinking skills.
\end{abstract}

Keywords-Scientific thinking skills; Discovery model; Inquiry model; Science teacher

\section{INTRODUCTION}

The application of the 2013 curriculum in Indonesia requires the ability of teachers in scientific thinking. All subjects, especially science, use active learning models that demand maximum student involvement in learning. The active learning model that is highly recommended for use in science learning is the discovery and inquiry models. Through these models, students are engaged to explore and construct their knowledge independently even in the guidance of teachers through prepared learning facilities. The teachers are not just present science matterial but must have the ability to facilitate students learning to construct their own knowledge.

Unfortunately, in our field experiences, many science teachers were found unable to implement inquiry and discovery in their classroom. They also cannot distinguish discovery and inquiry models in their learning plans and in science classrooms. Consequently, the teachers cannot facilitate students to construct their knowledge incependetly. [11] pointed out the scientific thinking skills of the teachers caused the difficulty in implementing discovery and inquiry models. Scientific thinking skills are often referred to as process skills, basically are the ability to apply scientific methods, starting from identifying and formulating problem or question, formulating hypotheses, designing experiment to collecting data, analyzing data, to drawing conclusions [11].

Scientific thinking skills are basically a combination of deductive thinking and inductive thinking. Scientific thinking skills are needed in learning that uses models or approaches that use scientific processes, such as: inquiry learning models and discovery models. Deductive thinking is in principle a scientific process that starts from facts or concepts or principles or theories that are generally applicable to study and construct knowledge, such as: facts, concepts, theories that are specific. Instead, think inductively, examine and process specific information to produce general information or knowledge. Both of these thinking skills are needed in learning that involves religious processes [5].

According to [4] discovery model learning is very promising because it involves students actively constructing 
their knowledge through experimental activities. In order for discovery learning to succeed, students must have discovery skills, including: formulating hypotheses, designing experiments, predicting, and analyzing data and regulative skills, such as planning and monitoring [7]. Discovery learning stages include: stimulating students through observation of facts and events, formulating problems/questions, collecting data, analyzing data, verifying data, and making generalizations (conclusions). With these stages, both teachers and students are required to be able to think scientifically that will help the learning process succeed in achieving its goals.

Inquiry learning in principle aims to investigate because of curiosity through a scientific process. In Indonesia, this inquiry model is often referred to as a scientific approach, that is observing, asking, collecting data, associating, concluding, and communicating. Inquiry is considered as an attempt to find truth, information, and knowledge [10]. Inquiry is also often synonymous with the terms investigation, research, questioning, or finding out. In learning, inquiry is a learning strategy or process skill [1]. Inquiry is considered successful if it already knows something previously unknown [2].

The inquiry learning model steps are almost the same as discovery models, but the results are not always in the form of generalizations. [8] describes the main steps of inquiry, namely: 1) identifying questions and concepts that guide investigation, 2) designing and investigating, 3) using tools and mathematics to develop investigation and communication, 4) formulating and revising scientific explanations and the model uses theory and facts, analyzes explanations and alternative models, and 5) communicates and produces scientific arguments.

Efforts to trigger students constructing knowledge are through discovery and inquiry models, teachers more frequently presents information or knowledge through the phenomenon of students' daily lives [9]. However, constructing knowledge through contexts is not easy because it requires the ability to think scientifically and learn transformation, both teachers and students [6].

The problem that is used as the focus in this study is how scientific thinking skills of science teachers who have difficulty understanding and implementing discovery and inquiry learning models. In addition, this study also examines the factors that cause science teachers to have difficulty distinguishing discovery and inquiry learning models in science learning.

\section{METHOD}

To answer the research focus question, we used a case study design to describe the scientific thinking skills of science teachers in relation to the difficulty of understanding and distinguishing discovery and inquiry learning models. Participants in this study were junior high school science teachers in East Lombok district who claimed they could not distinguish how to operate discovery learning models and inquiry learning models in science learning. Participants were taken randomly as many as 16 people.

The instrument used is a simple scientific thinking ability test of 10 multiple-choice items that are specifically designed to diagnose aspects of inductive thinking and deductive thinking that are widely used in discovery learning models and inquiry learning models. In addition, this study also uses an understanding test of the discovery and the inquiry models.

Data collection was carried out in two stages, namely providing a test of understanding the operation of discovery learning models and inquiry learning models and scientific thinking ability tests. Data analysis was carried out through content analysis of participants' answers to trace the causes of participants unable to distinguish the operation of discovery learning models and inquiry models. The factors that cause teacher difficulties are then described through percentage analysis.

\section{RESULTS AND DISCUSSION}

The results of the study consist of two parts, namely the description of the results of the participants' understanding of discovery learning models and inquiry learning models and descriptions of the causes of difficulty of science teachers to distinguish discovery learning models and inquiry models in science learning.

TABLE I. LAYOUT OF THE DIFFICULTY OF THE TEACHER

UNDERSTANDING AND DISTINGUISHING THE DISCOVERY MODEL AND THE MODEL OF INQUIRY IN SCIENCE LEARNING

\begin{tabular}{|c|c|c|}
\hline $\begin{array}{l}\text { Scientific } \\
\text { thinking }\end{array}$ & $\begin{array}{c}\text { Teachers' difficulty in } \\
\text { distiguishing discovery and } \\
\text { inquiry models in science } \\
\text { classroom }\end{array}$ & $\begin{array}{l}\text { Percentage } \\
\text { of teachers } \\
(\%)\end{array}$ \\
\hline $\begin{array}{l}\text { Problem/ } \\
\text { question }\end{array}$ & $\begin{array}{l}\text { 1. Problems types refer to } \\
\text { discovery or inquiry } \\
\text { models }\end{array}$ & 100 \\
\hline Hypothesize & $\begin{array}{l}\text { 1. Hypothesize forumula } \\
\text { refer to discovery or } \\
\text { inquiry models } \\
\text { 2. Hypothesize generation } \\
\text { 3. Hypthesize statement }\end{array}$ & 100 \\
\hline Data & $\begin{array}{l}\text { 1. Data for discovery or } \\
\text { inquiry } \\
\text { 2. Data analysis } \\
\text { 3. Data display }\end{array}$ & 100 \\
\hline Conclusion & Generalization or cases & 100 \\
\hline
\end{tabular}

Based on the data in Table I, the science teacher considers that the formulation of the problem, hypothesis, data characteristics and conclusions in the learning model of discovery and model inquiry are the same. This shows that the science teacher cannot distinguish the characteristics of the operations of discovery learning models and inquiry learning models. 


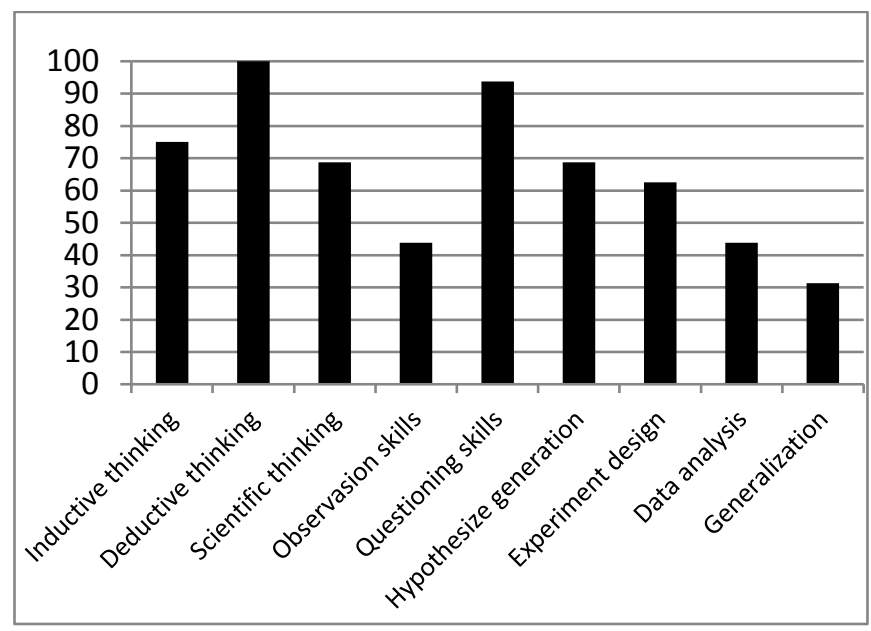

Fig. 1. The science teachers' difficulty in operating scientific their thinking skills

Figure 1 shows that teachers most difficult to operate deductive thinking. Teachers are also have difficulty in questioning skills that trigger deductive thinking. The detailed thinking skills difficulties of the science teachers are shown in Table II.

\section{TABLE II. SCIENTIFIC THINKING SKILLS OF SCIENCE} TEACHERS

\begin{tabular}{|c|c|c|}
\hline $\begin{array}{c}\text { Scientific } \\
\text { thinking } \\
\text { skills }\end{array}$ & $\begin{array}{l}\text { Teachers' difficulty to use their } \\
\text { scientific thinking }\end{array}$ & $\begin{array}{c}\text { Teacher } \\
\text { Percentage } \\
(\%)\end{array}$ \\
\hline $\begin{array}{l}\text { Induktive and } \\
\text { deductive } \\
\text { thinkings }\end{array}$ & $\begin{array}{l}\text { Statements are generated from: } \\
\text { Induktive thinking } \\
\text { Deduktive thinking } \\
\text { Scientific thinking }\end{array}$ & $\begin{array}{c}75 \\
100 \\
68.75\end{array}$ \\
\hline $\begin{array}{l}\text { Observation } \\
\text { skills }\end{array}$ & $\begin{array}{l}\text { Observe facts / phenomena that trigger } \\
\text { inductive thinking } \\
\text { Observe facts / phenomena that trigger } \\
\text { deductive thinking }\end{array}$ & $\begin{array}{c}0 \\
43.75\end{array}$ \\
\hline $\begin{array}{l}\text { Questioning } \\
\text { skills }\end{array}$ & $\begin{array}{l}\text { Problem/Question formulation } \\
\text { Question that trigger inductive thinking } \\
\text { Question that trigger deductive thinking }\end{array}$ & $\begin{array}{l}43.75 \\
56.25 \\
93.75 \\
\end{array}$ \\
\hline $\begin{array}{l}\text { Hypothesize } \\
\text { generation }\end{array}$ & $\begin{array}{l}\text { Determine the hypothesis formulation } \\
\text { that is appropriate for a } \\
\text { problem/question }\end{array}$ & 68.75 \\
\hline $\begin{array}{l}\text { Experiment } \\
\text { designing }\end{array}$ & $\begin{array}{l}\text { - Variabel identification } \\
\text { - Distinguish questions that require } \\
\text { activities } \\
\text { 1. Experiment } \\
\text { 2. Observation }\end{array}$ & $\begin{array}{c}6.25 \\
62,50 \\
25\end{array}$ \\
\hline Data analysis & $\begin{array}{l}\text { Interpret data that display as: } \\
\text { Data in table } \\
\text { News of facts }\end{array}$ & $\begin{array}{l}31,25 \\
43,75 \\
\end{array}$ \\
\hline Generalization & Conclusion & 31,25 \\
\hline
\end{tabular}

Based on Table II, it appears that science teachers have difficulty distinguishing inductive thinking processes, deductive thinking processes, and scientific thinking processes. These difficulties also appear in identifying statements and or questions that trigger the use of inductive thinking processes and deductive thinking processes, although more than $50 \%$ of teachers can follow the scientific thinking process. More than $50 \%$ of teachers also have difficulties in formulating hypotheses that are appropriate to the problem or question.

TABLE III. SOME EXAMPLES OF THE APPLICATION OF SCIENTIFIC THINKING SKILLS IN SCIENCE LEARNING OF DISCOVERY AND INQUIRY MODELS

\begin{tabular}{|c|c|c|c|}
\hline \multicolumn{2}{|c|}{$\begin{array}{l}\text { Inductive thinking in discovery } \\
\text { learning model }\end{array}$} & \multicolumn{2}{|c|}{$\begin{array}{l}\text { Inductive thinking in } \\
\text { inquiry learning model }\end{array}$} \\
\hline \multicolumn{2}{|c|}{$\begin{array}{l}\text { Are all meatballs in the city of East } \\
\text { Lombok containing dangerous } \\
\text { artificial additives? }\end{array}$} & \multicolumn{2}{|c|}{$\begin{array}{l}\text { Does Pak B's meatballs } \\
\text { contain dangerous artificial } \\
\text { additives? }\end{array}$} \\
\hline \multicolumn{2}{|c|}{$\begin{array}{l}\text { 1. All meatballs in the city of East } \\
\text { Lombok do not contain harmful } \\
\text { artificial additives } \\
\text { 2. Not all meatballs in the city of } \\
\text { East Lombok contain dangerous } \\
\text { additive }\end{array}$} & \multicolumn{2}{|c|}{$\begin{array}{l}\text { Pak B's meatballs contains } \\
\text { harmful artificial additives }\end{array}$} \\
\hline $\begin{array}{l}\text { Meatballs } \\
\text { type }\end{array}$ & Food Additive & Foods & $\begin{array}{l}\text { Food } \\
\text { Additives }\end{array}$ \\
\hline A & Positive & Meat-balls & Positive \\
\hline B & Positive & Tofu & Positive \\
\hline $\mathrm{C}$ & Positive & Noodles & Positive \\
\hline D & Negative & Salty fish & Positive \\
\hline \multicolumn{2}{|c|}{$\begin{array}{l}\text { 1. All meatballs in the city of East } \\
\text { Lombok do not contain harmful } \\
\text { artificial additives } \\
\text { 2. Not all meatballs in the city of } \\
\text { East Lombok contain dangerous } \\
\text { additives }\end{array}$} & \multicolumn{2}{|c|}{$\begin{array}{l}\text { Meatballs, tofu, noodles and } \\
\text { salted fish in Lombok Pak B } \\
\text { contain dangerous artificial } \\
\text { additives }\end{array}$} \\
\hline
\end{tabular}

Based on the data shown in Table I and Table II, it appears that science teachers have difficulty operating their scientific thinking skills. These difficulties include distinguishing the characteristics of scientific questions, both those that trigger inductive thinking skills and deductive thinking skills. Of the three categories of thinking abilities examined in this study, teachers generally have difficulties in operating deductive thinking skills, inductive thinking skills, and scientific thinking abilities. As a result, science teachers cannot distinguish characteristics of problems or questions that trigger the use of these thought processes. Mistakes in operating this scientific thinking ability were also reviewed by [11] who discovered 10 teachers' mistakes in operating their scientific thinking abilities.

The success of science learning using discovery and inquiry models is very much determined by the scientific thinking skills of teachers and students [5]. Even according to [7], the two learning models also require the ability to manage and manage, especially in terms of planning and monitoring. In the case of science teachers who have difficulty distinguishing between learning and inquiry models, it is an indication that science teachers are still having difficulty operating their scientific thinking skills. The impact is the teacher's inability to facilitate student learning through scientific processes or investigation.

The failure of teachers in facilitating student learning through discovery and inquiry learning can produce 
students' thinking habits that deviate from scientific thinking processes or habits of mind [3]. If this happens students will have difficulty constructing the knowledge expected by the 2013 curriculum, and can even lead to student confusion. Students experience difficulties or fail to observe the facts or phenomena provided or oriented by the teacher. The teacher cannot orient and even identify the facts or phenomena of the science that students should be observing, causing disruption of the inquiry process that triggers students to ask questions. In this case, the teacher often finds students not asking because information or phenomena facilitated by the teacher does not trigger students to ask.

Difficulties in asking will cause the next process to be difficult to continue because scientific thinking skills and student inquiry skills are not stimulated properly. As a result, the teacher asks questions and guides students to follow the scientific thinking process that the teacher wants, as in the learning of structured type inquiry models. The scientific process designed by the teacher is still questionable when the teacher also has difficulty operating his scientific thinking skills.

Teachers who have difficulty operating their scientific thinking skills will be wrong in orienting students both in observing and identifying questions. As many as\% of teachers orient students to identify the question: "Why can methanil yellow cause irritation to the digestive tract?" In part, "Where did the seller know to get the dangerous substance?" Some teachers want students to ask: "how to distinguish tofu that contains methanil yellow dye and know that does not contain yellow methanil?" These three types of questions trigger different scientific investigative processes in students which ultimately produce different knowledge. In the first instance, students will construct methanil yellow properties that cause irritation of the digestive tract that students can access via the internet. In the second question, students will be able to find out if they ask the tofu seller or the person who knows the know-how gets the information that contains the methanil yellow. In the third question, students will conduct an investigation in the form of identifying how to distinguish tofu containing yellow methanil and not. The third question is very relevant to the problems faced by the community and can be investigated by students, while the first and second questions can be known by students through information tracing directly through the literature or asking the seller who is less relevant to the problems presented in the facts

\section{CONCLUSION}

Conclusions that can be drawn from this study, namely the teacher has difficulty operating the ability to think scientifically, especially the ability to think deductively. As a result, teachers cannot facilitate student learning optimally, ranging from presenting facts or phenomena that trigger students to ask questions, investigate, process data, and produce conclusions. Students become knowledge difficulties that are expected to be achieved by the curriculum. The main causes of teacher difficulties in discovery and inquiry model learning are the difficulty of teachers in operating inductive thinking skills and deductive thinking, starting from identifying problems or questions, formulating hypotheses, designing and conducting experimental activities, processing data, and drawing conclusions.

\section{REFERENCES}

[1] C. Barman, "Guest editorial: How do you define inquiry?," Science \& Chil., vol. 40, pp. 8-9, October 2002.

[2] L.H. Barrow, "A brief history of inquiry: From dewey to Standards," J. of Science Teach. Education, vol. 17, pp. 265-278, March 2006.

[3] P. Cranton, Understanding and promoting transformative learning: A guide for educators of adults, San Francisco: Jossey-Bass, 2006.

[4] W.V. Joolingen, "Cognitive tools for discovery learning," International J. of Artificial Intelligence in education, vol. 10, pp. 385-397, 1999.

[5] N. Lederman, "Letters: Learning about inquiry," Science \& Child., vol. 40, pp. 8-9, 2003.

[6] M.C. Linn and B.S. Elyon, "Science Education: Integrating view of learning and instruction," in P.A. Alexander \& P.H. Winne (Eds), Handbook of Educational Psychology (2nd ed.) (pp. 511-544). Mahwah, NJ: Erlbaum, 2006.

[7] M. Njoo, and T.D. Jong, "Exploratory learning with a computer simulation for control theory: Learning processes and instructional support," J. of Res. in Science Teach., vol. 30, pp. 821-844, 1993.

[8] National Research Council, Inquiry and the national science education standards, Washington, DC: National Academy Press, 2000.

[9] N.M. Potter, and T.L. Overton, "Chemistry in sport: context-based elearning in chemistry," Chemistry Education Res. and Practice, vol. 7, pp. 195-202, June 2006.

[10] Webster's Third International Dictionary, Springfield, MA: MerriamWebster, 1986.

[11] J.S. Wooley, A.M. Deal, J. Green, F. Hathenbruck, S. A. Kurtz, T.K. H. Park, S.V. Pollock, M.B. Transtrum, and J.L. Jensen, "Undergraduate Students Demonstrate Common False Scientific Reasoning Strategies," Thinking Skills and Creativity, vol. 27, pp. 101-113, March 2018. 